\title{
Selenium deficiency and the effects of supplementation on preterm infants
}

\author{
Deficiência de selênio e os efeitos da suplementação em prematuros \\ Deficiencia de selenio y los efectos de la suplementación en prematuros
}

\author{
Renata Germano B. O. N. Freitas ${ }^{1}$, Roberto José N. Nogueira², Maria Ângela R. G. M. Antonio ${ }^{1}$, Antonio de Azevedo Barros-Filho ${ }^{1}$, \\ Gabriel Hessel ${ }^{1}$
}

\section{ABSTRACT}

Objective: This study aimed to review the literature about blood concentrations of selenium associated with gestational age, feeding, supplementation and related clinical features in preterm infants.

Data sources: Systematic review in the following databases: MEDLINE, PubMed, Google academics, SciELO. org, ScienceDirect (Elsevier) and CINAHL-Plus with Full Text (EBSCO). Articles published up to January 2013 with the keywords "selenium deficiency", "selenium supplementation", "neonates", "infants", "newborn” and "preterm infants" were selected.

Data synthesis: The studies reported that low blood selenium levels are associated with increased risk of respiratory diseases. Preterm infants, especially with low birth weight, presented lower selenium levels. Selenium deficiency has also been associated with the use of oral infant formula, enteral and parenteral nutrition (with or without selenium addition). The optimal dose and length of selenium supplementation is not well-established, since they are based only on age group and selenium ingestion by breastfed children. Furthermore, the clinical status of the infant affected by conditions that may increase oxidative stress, and consequently, selenium requirements is not taken into account.

Conclusions: Prematurity and low birth weight can contribute to low blood selenium in premature infants. Selenium supplementation seems to minimize or prevent clinical complications caused by prematurity.

Key-words: review; selenium; supplementation; infant, newborn; infant, premature.

\section{RESUMO}

Objetivo: Revisar os trabalhos que analisaram as concentrações sanguíneas de selênio associadas à idade gestacional, à alimentação, à suplementação e ao quadro clínico de prematuros.

Fontes de dados: Revisão sistemática da literatura por meio de buscas eletrônicas nas seguintes bases de dados: MEDLINE PubMed, Google acadêmico, SciELO.org, ScienceDirect (Elsevier) e CINAHL-Plus with Full Text (EBSCO). Buscaram-se trabalhos publicados até janeiro de 2013 com as seguintes palavras-chave: "selenium deficiency", "selenium supplementation", "neonates", "infants", "newborn" e "preterm infants".

Síntese dos dados: Os estudos relataram que os baixos níveis selênio associam-se ao risco aumentado para doenças respiratórias. Os prematuros, principalmente com baixo peso ao nascer, apresentam os menores níveis de selênio. A deficiência do mineral tem sido associada ao uso de fórmula infantil oral, nutrição enteral e parenteral (com e sem adição de selênio). A dosagem e o tempo ideal para a suplementação de selênio ainda não estão bem estabelecidos, visto que se baseiam apenas na faixa etária e na ingestão do mineral por crianças amamentadas no peito. Além disso, não se considera o quadro clínico do recém-nascido, que pode ser acometido de doenças que aumentam o estresse oxidativo e, consequentemente, elevam as necessidades de selênio.

Conclusões: A prematuridade e o baixo peso ao nascer podem contribuir para reduzir as concentrações sanguíneas de selênio em prematuros. A suplementação parece minimizar ou prevenir as complicações clínicas causadas pela prematuridade.

Palavras-chave: revisão; selênio; suplementação; recém-nascido; prematuro.
Instituição: Universidade Estadual de Campinas (Unicamp), Campinas, SP, Brasil

'Faculdade de Ciências Médicas da Unicamp, Campinas, SP, Brasil ${ }^{2}$ Hospital de Clínicas da Unicamp, Campinas, SP, Brasil.
Endereço para correspondência:

Renata Germano B. O. N. Freitas

Rua Tessália Vieira de Camargo, 126 - Barão Geraldo

CEP 13083-887 - Campinas/SP

E-mail: renatagbonfreitas@yahoo.com.br

Conflito de interesse: nada a declarar

Recebido em: 6/6/2013

Aprovado em: 1/8/2013 


\section{RESUMEN}

Objetivo: Revisar los trabajos que analizaron las concentraciones sanguíneas de selenio asociadas con la edad gestacional, alimentación, suplementación y cuadro clínico de prematuros.

Fuentes de datos: Revisión sistemática de la literatura mediante búsquedas electrónicas en las bases de datos a continuación: Medline Pubmed, Google académico, SciELO. org, SienceDirect (Elsevier) y CINAHL with Full Text (EBSCO). La búsqueda se realizó con trabajos publicados hasta enero de 2013 con las palabras clave a continuación: selenium deficiency, selenium supplementation, neonates, infants, newborn and preterm infants.

Síntesis de los datos: Los estudios relataron que los bajos índices de selenio están asociados al riesgo aumentado para enfermedades respiratorias. Los prematuros, principalmente con bajo peso al nacer, presentan los menores niveles de selenio. La deficiencia de selenio viene siendo asociada al uso de fórmula infantil oral, nutrición enteral y parenteral (con y sin adición de selenio). La dosis y el tiempo ideal para la suplementación de selenio todavía no están bien establecidos, puesto que se basan solamente en la franja de edad y en la ingestión de selenio de niños amamantados al pecho. Además, no se considera el estado clínico del recién nacido, que puede ser acometido por enfermedades que aumentan el estrés oxidativo y, por consiguiente, elevan las necesidades de selenio.

Conclusiones: La prematuridad y el bajo peso al nacer pueden contribuir para reducir las concentraciones sanguíneas de selenio en prematuros. La suplementación parece reducir o prevenir las complicaciones clínicas causadas por la prematuridad.

Palabras clave: revisión sistemática; deficiencia de selenio; suplementación de selenio; recién nacido; prematuro.

\section{Introduction}

Selenium is a trace element considered essential due to its participation in major metabolic functions ${ }^{(1,2)}$, immune system, thyroid hormone metabolism ${ }^{(1,2)}$, male infertility, neoplasms and cardiovascular disease ${ }^{(2)}$. It also has antioxidant properties ${ }^{(1,3)}$.

Selenium is an active-site component of glutathione peroxidase $(\mathrm{GPx})^{(4)}$. This enzyme contains four atoms of selenium and is responsible for nearly $30 \%$ of plasma selenium levels ${ }^{(1,5)}$. GPx has antioxidant function ${ }^{(3)}$, thereby protecting body cells from oxidation and reducing toxic substances caused by oxidative stress ${ }^{(6)}$.

In 1979, it was discovered that selenium supplementation could prevent the appearance of Keshan disease, a cardiomyopathy affecting children living in regions of selenium-deficient soil ${ }^{(7)}$. In the pediatric population, selenium deficiency is most commonly found in preterm infants, associated with gestational age, feeding after birth and clinical status ${ }^{(8-10)}$.

According to the National Health and Medical Research Council (NH\&MRC, 2006) ${ }^{(11)}$, the daily recommended oral dose of selenium is $12-15 \mu \mathrm{g}$. For enteral nutrition, the recommended dose is $1.3-3.0 \mu \mathrm{g} / \mathrm{kg} /$ day. For parenteral nutrition, the European Society for Paediatric Gastroenterology, Hepatology and Nutrition (ESPGHAN, 2005) $)^{(12)}$ has recommended the administration of $2-3 \mu \mathrm{g} / \mathrm{kg} /$ day. Currently, the American Society for Parenteral and Enteral Nutrition (ASPEN, 2012) ${ }^{(13)}$ suggested an improvement of recommended intake of selenium from $20-60 \mu \mathrm{g} /$ day to $60-100 \mu \mathrm{g} / \mathrm{day}$ for adults. With respect to pediatric patients, including neonates, the recommended dose remained $2 \mu \mathrm{g} / \mathrm{kg} / \mathrm{day}^{(13-16)}$.

The addition of selenium to oral, enteral and parenteral infant formulas is not a routine practice in all countries and health care services. In Brazil, selenium is not routinely added to parenteral nutrition, despite studies reporting that selenium supplementation may prevent or correct a deficiency in this mineral ${ }^{(17-19)}$.

This study aimed to review the literature about blood selenium concentrations in preterm infants associated with gestational age, feeding, supplementation and related clinical features.

\section{Method}

A systematic review was conducted by electronic search. Medline Pubmed, Google Scholar and Capes Platform databases were used for a refined search in the following databases: SciELO.org, ScienceDirect (Elsevier) and CINAHLPlus with Full Text (EBSCO). Searches were made of studies published up to January, 2013 with the following keywords: selenium deficiency, selenium supplementation, neonates, newborn, preterm infants. No limitations were applied regarding date of publication and language. The exclusion criteria were as follows: review papers, animal research, studies with dead children and studies with inadequate age group. For data collection, Boolean operators that broadened or restricted the number of articles identified by the search system were used. 
Table 1 - Type of study, location, case study, feeding form and conclusion in selected studies

\begin{tabular}{|c|c|c|c|c|}
\hline Author/year & $\begin{array}{l}\text { Type of } \\
\text { study }\end{array}$ & Country & Population & Feeding \\
\hline \multirow[t]{2}{*}{$\begin{array}{l}\text { Amin et al, } \\
1980^{(28)}\end{array}$} & $\begin{array}{l}\text { Study 1: } \\
\text { Cross- } \\
\text { sectional }\end{array}$ & USA & $\begin{array}{c}\text { Study 1: } 68 \text { preterm infants } \\
\text { (GA 28-36wks.), } 18 \text { term infants, } \\
50 \text { normal children. }\end{array}$ & \multirow[t]{2}{*}{ PN and $F$} \\
\hline & $\begin{array}{l}\text { Study 2: } \\
\text { Longitudinal }\end{array}$ & & $\begin{array}{c}\text { Study } 2: 8 \text { preterm infants with severe } \\
\text { respiratory insufficiency. Assessment } \\
\text { until the } 6^{\text {th }} \text { wk of age. }\end{array}$ & \\
\hline $\begin{array}{l}\text { Lockitch et al, } \\
\text { 1989(21) }\end{array}$ & $\begin{array}{l}\text { Prospective } \\
\text { observational } \\
\text { longitudinal }\end{array}$ & Canada & $\begin{array}{l}\text { Baseline: } 56 \text { healthy term newborns } \\
\text { and } 39 \text { LBW infants with a mean (SD) } \\
\text { BW of } 1940 \pm 257 \mathrm{~g} \text { and } 35 \text { VLBW } \\
\text { infants of } 1064 \pm 264 \mathrm{~g} \text { with }<37 \mathrm{wks} \text {. of } \\
\text { gestation. Assessment until the } 7^{\text {th }} \text { wk } \\
\text { of life in } 16 \text { preterm infants. }\end{array}$ & $\begin{array}{l}\text { PN (without Se) with or } \\
\text { without oral intake. }\end{array}$ \\
\hline $\begin{array}{l}\text { Huston et al, } \\
1991^{(47)}\end{array}$ & $\begin{array}{l}\text { Prospective } \\
\text { Randomized } \\
\text { Clinical Trial }\end{array}$ & USA & $\begin{array}{c}20 \text { preterm infants }(\mathrm{BW}<1000 \mathrm{~g}) \text {. } \\
\text { The mean }(\mathrm{SD}) \mathrm{GA} \text { in } \mathrm{G} 1=26.7 \pm 1.5 \\
\text { and } \mathrm{G} 2=26.5 \pm 1.2 \text { wks. Assessment } \\
\text { until the } 60 \text { th day. }\end{array}$ & $\begin{array}{l}\text { PN and EN. G1 ( } \mathrm{n}=10 ; \\
1.34 \mu \mathrm{g} / \mathrm{kg} / \mathrm{day} \text { of selenious } \\
\text { acid) and G2 (without Se). }\end{array}$ \\
\hline $\begin{array}{l}\text { Smith et al, } \\
1991^{(29)}\end{array}$ & $\begin{array}{l}\text { Prospective } \\
\text { Clinical Trial }\end{array}$ & USA & $\begin{array}{c}46 \text { preterm infants }(\mathrm{BW}<1700 \mathrm{~g}) \text {. The } \\
\text { mean GA was } 29.3 \text { weeks. Assessment } \\
\text { until the } 3 \text { th wk of life. }\end{array}$ & $\begin{array}{c}\text { BF ( }=21 ; 24 n g \mathrm{Se} / \mathrm{mL}) \\
\mathrm{F}(\mathrm{n}=13 ; 7.8 \mathrm{ng} \mathrm{Se} / \mathrm{mL}) \text {, and } \\
\mathrm{F}(\mathrm{n}=12 ; 34.8 \mathrm{ng} \mathrm{Se} / \mathrm{mL})\end{array}$ \\
\hline $\begin{array}{l}\text { Mask et al, } \\
1993^{(27)}\end{array}$ & $\begin{array}{l}\text { Cross- } \\
\text { sectional }\end{array}$ & USA & $\begin{array}{c}13 \text { preterm newborns (Mean (SD) } \\
\text { BW and GA was } 1869 \pm 449 \mathrm{~g} \text { and } \\
33.5 \pm 1.8 \text { wks.), } 15 \text { term newborns and } \\
\text { their mothers and } 15 \text { women who were } \\
\text { not pregnant. }\end{array}$ & (Not differentiated) \\
\hline $\begin{array}{l}\text { Darlow et al, } \\
1995^{(32)}\end{array}$ & $\begin{array}{l}\text { Prospective } \\
\text { observational } \\
\text { longitudinal }\end{array}$ & New Zealand & $\begin{array}{l}79 \text { preterm newborns with a mean (SD) GA } \\
\text { of } 28.3 \pm 2.5 w k s \text {. And BW of } 1164 \pm 254 \mathrm{~g} \text {. } \\
\text { Assessment until the } 28^{\text {th }} \text { day of life. }\end{array}$ & $\begin{array}{l}\text { PN (without Se), EN and } \\
\text { BF or } F \text {. }\end{array}$ \\
\hline $\begin{array}{l}\text { Daniels et al, } \\
1996^{(18)}\end{array}$ & $\begin{array}{l}\text { Prospective } \\
\text { Randomized } \\
\text { Clinical Trial }\end{array}$ & Australia & $\begin{array}{c}\text { Preterm newborns ( } \mathrm{G} 1: 19 \text { and } \mathrm{G} 2: 19) \\
\text { healthy term newborns (RG=32). The } \\
\text { mean (SD) BW and } \mathrm{GA} \text { were } 1171 \pm 38 \mathrm{~g} \\
\text { and } 29 \pm 0.3 \mathrm{wks} \text {. Assessment until the } \\
6 \text { th wk of life. }\end{array}$ & 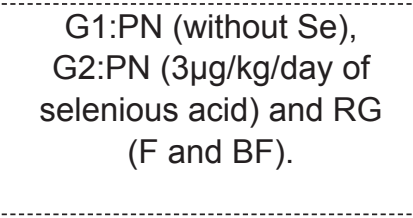 \\
\hline $\begin{array}{l}\text { Bogye et al, } \\
1998^{(51)}\end{array}$ & $\begin{array}{l}\text { Randomized } \\
\text { Clinical Trial }\end{array}$ & Hungary & $\begin{array}{l}36 \text { preterm newborns with VLBW. } \\
\text { BW of } 975 \pm 122 \mathrm{~g} \text { and GA } 27 \pm 1 \mathrm{wk} \text {. } \\
\text { Supplementation for } 14 \text { days. }\end{array}$ & 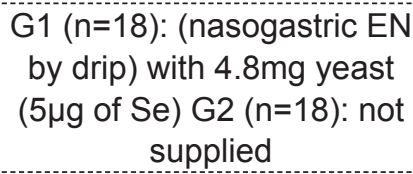 \\
\hline $\begin{array}{l}\text { Bogye et al, } \\
1998^{(38)}\end{array}$ & $\begin{array}{l}\text { Randomized } \\
\text { Clinical Trial }\end{array}$ & Hungary & $\begin{array}{l}28 \text { preterm newborns with birth weight } \\
\text { and GA of } 962 \pm 129 \mathrm{~g} \text { and } 27 \pm 1 \text { wk. } \\
\text { Supplementation for } 14 \text { days. }\end{array}$ & $\begin{array}{l}\text { G1 ( } n=14) \text { : (nasograstric } \\
\text { EN by drip) with } 4.8 \mathrm{mg} \text { of } \\
\text { yeast }(5 \mu \mathrm{g} \text { of } \mathrm{Se}) \text {. } \\
\mathrm{G} 2(\mathrm{n}=14) \text { : not supplied }\end{array}$ \\
\hline $\begin{array}{l}\text { Merz et al, } \\
1998^{(40)}\end{array}$ & Prospective & Germany & $\begin{array}{l}34 \text { VLBW infants with GA and BW } \\
28.6 \pm 2.5 \text { wks. and } 1075 \pm 249 \mathrm{~g} \text { respectively. } \\
\text { Assessment until } 4^{\text {th }} \text { wk of life. }\end{array}$ & $\begin{array}{l}\text { Mainly PN and were not } \\
\text { specifically supplied with } \\
\text { Se. }\end{array}$ \\
\hline $\begin{array}{l}\text { Klinger et al, } \\
1999^{(39)}\end{array}$ & $\begin{array}{l}\text { Cross- } \\
\text { sectional }\end{array}$ & Israel & $\begin{array}{l}29 \text { VLBW infants with mean (SD) age } \\
\text { and weight } 26 \pm 1.7 \text { wks and } 809 \pm 129 \mathrm{~g}\end{array}$ & Se: $2 \mu \mathrm{g} / \mathrm{kg} / \mathrm{d}$ selenious acid. \\
\hline \multirow[t]{2}{*}{$\begin{array}{l}\text { Darlow et al, } \\
2000^{(24)}\end{array}$} & $\begin{array}{l}\text { Double-blind } \\
\text { placebo- } \\
\text { controlled } \\
\text { randomized }\end{array}$ & New Zealand & $\begin{array}{l}534 \text { infants with } \mathrm{BW}<1500 \mathrm{~g} \\
\text { Assessment until } 36 \mathrm{wks} \text { of life. }\end{array}$ & $\begin{array}{l}\mathrm{PN}: 7 \mu \mathrm{g} / \mathrm{kg} / \mathrm{d} \text { and } \\
\mathrm{F}: 5 \mu \mathrm{g} / \mathrm{kg} / \mathrm{day} \text { sodium } \\
\text { selenite. }\end{array}$ \\
\hline & Trial & & & \\
\hline
\end{tabular}


Table 1 - Continuation

\begin{tabular}{|c|c|c|c|c|}
\hline Author/year & $\begin{array}{l}\text { Type of } \\
\text { study }\end{array}$ & Country & Population & Feeding \\
\hline $\begin{array}{l}\text { Winterbourn } \\
\text { et al, } 2000^{(48)}\end{array}$ & $\begin{array}{l}\text { Randomized } \\
\text { controlled } \\
\text { Trial }\end{array}$ & New Zealand & $\begin{array}{c}173 \text { newborns with weight <1500g. } \\
\text { Assessment until } 36 w k s \text { of life. }\end{array}$ & $\begin{array}{c}\text { PN: } 7 \mu \mathrm{g} / \mathrm{kg} / \mathrm{d} \text { and } \\
\mathrm{F}: 5 \mu \mathrm{g} / \mathrm{kg} / \mathrm{day} \text { sodium } \\
\text { selenite. }\end{array}$ \\
\hline $\begin{array}{l}\text { Sievers et al, } \\
2001^{(45)}\end{array}$ & $\begin{array}{l}\text { Prospective } \\
\text { observational } \\
\text { longitudinal }\end{array}$ & Germany & $\begin{array}{l}16 \text { preterm newborns (GA 25-32wk and } \\
\text { BW 595-1495g), } 14 \text { term newborns } \\
\text { with F and } 17 \text { term newborns with BF. } \\
\text { Assessment until } 1^{\text {st }} \text { year of life. }\end{array}$ & $\begin{array}{l}\mathrm{BF}, \mathrm{F} \text { and complementary } \\
\text { feeding. }\end{array}$ \\
\hline $\begin{array}{l}\text { Makhoul et al, } \\
2004^{(8)}\end{array}$ & $\begin{array}{l}\text { Cross- } \\
\text { sectional }\end{array}$ & Israel & $\begin{array}{c}165 \text { preterm newborns and term } \\
\text { newborns (24-42wks.) and their } \\
\text { mothers. }\end{array}$ & (Not differentiated) \\
\hline $\begin{array}{l}\text { Mentro et al, } \\
2004^{(9)}\end{array}$ & $\begin{array}{l}\text { Prospective } \\
\text { observational } \\
\text { longitudinal }\end{array}$ & $\begin{array}{l}14 \text { Caucasians, } \\
3 \text { Hispanics } \\
\text { and } 1 \text { Asian- } \\
\text { American }\end{array}$ & $\begin{array}{c}18 \text { preterm newborns with BW of } \\
1013 \mathrm{~g}(650-1370 \mathrm{~g}) \text { and risk of BPD. } \\
\text { Mean GA was } 27 \text { weeks. Assessment } \\
\text { until } 4^{\text {th }} \text { week of life. }\end{array}$ & $\begin{array}{l}\text { BF, PN, EN and F. Mean } \\
\text { ingestion of Se in the } 1^{\text {st }} \\
\text { wk was } 0.82 \mu \mathrm{g} / \mathrm{kg} / \text { day and } \\
1.7 \mu \mathrm{g} / \mathrm{kg} / \text { day in the } 4^{\text {th }} \text { wk. }\end{array}$ \\
\hline $\begin{array}{l}\text { Galinier et al, } \\
2005^{(30)}\end{array}$ & $\begin{array}{l}\text { Cross- } \\
\text { sectional }\end{array}$ & France & $\begin{array}{l}248 \text { preterm newborns and } 262 \\
\text { term newborns. The mean GA and } \\
\text { BW }(S D) \text { for preterm newborns was } \\
32.4 \pm 2.52 \text { ws. and } 1845 \pm 489 \mathrm{~g} \text {. }\end{array}$ & (Not differentiated) \\
\hline $\begin{array}{l}\text { Nassi et al, } \\
2009^{(10)}\end{array}$ & $\begin{array}{l}\text { Prospective } \\
\text { observational } \\
\text { longitudinal }\end{array}$ & Italy & $\begin{array}{c}30 \text { preterm infants with mean (SD) } \\
\text { BW and GA of } 1605 \pm 122 \mathrm{~g} \text { and } \\
34.5 \pm 0.5 \mathrm{wk} \text {. The control group } \\
\text { included } 30 \text { term infants. Assessment } \\
\text { until the } 100^{\text {th }} \text { day of life. }\end{array}$ & $\mathrm{BF}$ \\
\hline
\end{tabular}

BF: breastfed; BPD: bronchopulmonary dysplasia; BW: birth weight; EN: enteral nutrition; G: group; GA: gestational age; F: oral infant formula; LBW: low birth weight; PN: parenteral nutrition; RG: reference group; SD: standard deviation; Se: selenium; VLBW: very low birth weight; Wk: week.

One hundred and eighty-nine (189) articles were found. Of these, 18 were selected and 171 excluded (63 repeated studies, 50 animal studies, 14 review articles, 27 with inadequate age group, 11 did not address the topic, 6 reported dead children).

Thus, based on titles and abstracts, 18 studies were chosen for this systematic review. After the selection of studies, level of evidence and grades of recommendation were classified according to Brazilian Medical Association ${ }^{(20)}$.

\section{Results}

Eighteen articles analyzing selenium concentrations in preterm infants were selected. Table 1 shows study design, population characteristics and forms of feeding. According to the criteria of the Brazilian Medical Association ${ }^{(20)}$, studies were classified as A or B. In table 2, a relationship between selenium status and age of the child is observed.

Concerning birth weight, Makhoul et al ${ }^{(8)}$ observed that the lower the weight, the lower the selenium concentration $(\mathrm{r}=0.237 ; p=0.002)$. Lockitch et $a^{(21)}$ found a significant correlation between BW and plasma Se $(\mathrm{r}=0.47 ; p<0.001)$. Plasma GPx levels were more highly correlated with birth weight $(\mathrm{r}=0.64 ; p<0.001)$. In addition, studies have related alterations in selenium concentration and clinical status (Table 3).

Table 4 shows studies correlating the amount of selenium provided by feeding routes used with selenium concentrations observed in studies of children.

\section{Discussion}

It is known that the pediatric population, particularly premature infants ${ }^{(8-10)}$, is vulnerable to low Se concentrations due to nutritional changes ${ }^{(22)}$, possible clinical complications ${ }^{(10,23)}$ and low selenium liver stores ${ }^{(8,9,24-26)}$. This occurs because of immature chorionic villi that acts in the transport of this mineral and also due to inadequate intestinal absorption ${ }^{(8,9,25,26)}$.

During pregnancy, maternal blood selenium levels decrease, reflecting a greater amount of selenium transported to the fetus in the 3rd trimester of pregnancy. Mask et $a l^{(27)}$, Amin et $a l^{(28)}$ and Smith et $a l^{(29)}$ suggest that low selenium values found in preterm infants must be associated 
Table 2 - Main results found in publications about the relationship between alterations in selenium status and age

\begin{tabular}{|c|c|}
\hline Author & Results \\
\hline Amin et al, 1980(28) & $\begin{array}{l}\text { The mean serum concentration in term infants }(0.098 \pm 0.025 \mu \mathrm{g} / \mathrm{mL}) \text { was slightly higher } \\
\text { than preterm infants }(0.032 \mu \mathrm{g} / \mathrm{ml}) \text {, but there was not difference significant. }\end{array}$ \\
\hline Lockitch et al, 1989(21) & $\begin{array}{l}\text { The mean concentration decreased from } 0.74 \pm 0.13 \text { to } 0.63 \pm 0.15 \mu \mathrm{mol} / \mathrm{L} \text { at day } 7 \\
(p=0.01) \text { and at day } 14 \text { decreased to } 0.51 \pm 0.19 \mu \mathrm{mol} / \mathrm{L}(p<0.001) \text {. Se values decreased } \\
\text { in all } 16 \text { preterm infants followed over the first } 50 \text { days. In } 11 \text { infants, levels dropped to } \\
<0.22 \mu \mathrm{mol} / \mathrm{L}(17 \mu / \mathrm{L}) \text {. }\end{array}$ \\
\hline Smith et al,1991(29) & $\begin{array}{l}\text { After } 3^{\text {th }} \text { week there were no significant differences of Se concentration between groups } \\
\text { (preterm infants with F and BF). }\end{array}$ \\
\hline Mask et al, 1993(27) & $\begin{array}{l}\text { The plasma Se was lower in preterm newborns }(0.08 \pm 0.02 \mu \mathrm{g} / \mathrm{mL}) \text { than term newborns } \\
(0.10 \pm 0.02 \mu \mathrm{g} / \mathrm{ml}), p=0.052 \text {. }\end{array}$ \\
\hline Darlow et al, 1995(32) & $\begin{array}{l}\text { There was no significant correlation between gestational period and plasma Se. The } \\
\text { correlations among GPx and plasma Se was weak at birth }(0.39) \text { and at } 28 \text { days (0.17). }\end{array}$ \\
\hline Merz et al, 1998(40) & $\begin{array}{l}\text { After birth the value of plasma Se was } 34.2 \mu \mathrm{g} / \mathrm{L} \text { and reduced to } 16.1 \mu \mathrm{g} / \mathrm{L} \text { after } 4 \text { weeks } \\
(p<0.001) .\end{array}$ \\
\hline Klinger et al, 1999(39) & $\begin{array}{l}\text { No correlation was observed between the plasma Se and gestational age }(r=0.27 \text {, } \\
p=0.16) \text {. There was significant correlation between gestational age and the level of T4 } \\
(r=0.45 ; p=0.02) \text {. }\end{array}$ \\
\hline Winterbourn et al, 2000(48) & There was no statistically significant difference in GA between the group with and without Se. \\
\hline Sievers et al, 2001(45) & $\begin{array}{l}\text { Plasma Se concentrations in preterm newborns were } 11.7(6.5-20.8) \mu \mathrm{g} / \mathrm{L} \text { (assessment in } \\
\text { the hospital). At } 4 \text { months: preterm newborns }=11.6(8.8-16.7) \mu \mathrm{g} / \mathrm{L} \text {, term newborns fed } \\
\text { with IF=31.3 }(24.3-47.5) \mu \mathrm{g} / \mathrm{L} \text { and term newborns } B F=45.6(27.1-65.1) \mu \mathrm{g} / \mathrm{L} \text {. }\end{array}$ \\
\hline Makhoul et al, 2004 ${ }^{(8)}$ & $\begin{array}{l}\text { Linear relationship between umbilical cord blood concentrations and } G A(r=0.341 \text {, } \\
p<0.0001) \text {. }\end{array}$ \\
\hline $\begin{array}{l}\text { Mentro, Smith, } \\
\text { Moyer-Mileur, 2004(9) }\end{array}$ & $\begin{array}{l}\text { Se concentrations decreased from the } 1^{\text {st }} \text { to } 4^{\text {th }} w k \text { of life. Plasma Se }(S D)=0.97 \pm 0.21 \mu \mathrm{mol} / L \\
\text { in the } 1^{\text {st }} w k \text { and } 0.72 \pm 0.27 \mu \mathrm{mol} / \mathrm{L} \text { in the } 4^{\text {th }} w k(p=0.001) \text {. There was not change in plasma } \\
\text { GPx among week } 1 \text { and } 4 \text {. The erythrocyte } G P x \text { increased along the time period }(t=-3.38 ; \\
p=0.004) \text { and was associated to the GA. }\end{array}$ \\
\hline Galinier et al, 2005(30) & $\begin{array}{l}\text { Se concentration increased with GA from } 0.4 \pm 0.1 \mu \mathrm{mol} / \mathrm{L}\left(26^{\text {th }} \text { to } 33^{\text {rd }} \text { week) to }\right. \\
0.5 \pm 0.1 \mu \mathrm{mol} / \mathrm{L} \text { (from the } 33^{\text {rd }} \text { to the } 37^{\text {th }} \text { week) and } 0.6 \pm 0.1 \mu \mathrm{mol} / \mathrm{L}\left(>37^{\text {th }} \text { weeks }\right)(p<0.001 \text {, } \\
r=0.593) \text {. }\end{array}$ \\
\hline Nassi et al, 2009(10) & $\begin{array}{l}\text { Up until } 20 \text { days postnatal, the GPx was lower in the preterm infants than in the } \\
\text { term infants. }\end{array}$ \\
\hline
\end{tabular}

BF: breastfed; GA: gestational age; GPx: glutathione peroxidase; Se: selenium.

with selenium accumulation during gestation. This fact was observed in studies by Makhoul et $a^{(8)}$ and Galinier et $^{\left(l^{(30)}\right.}{ }^{\text {, who }}$ analyzed umbilical cord selenium concentration and noted a significant association with gestational age of newborn infants. Selenium concentration increased after 36 weeks in the former study and from the $26^{\text {th }}$ to the $38^{\text {th }}$ week in the latter study.

Mentro, Smith and Moyer-Mileur ${ }^{(9)}$ suggested that preterm infant's small Se stores are used preferentially for GPx production, occurring in stable or increased GPx and decreased Se concentrations. This could explain the poor correlation between selenium and GPx concentrations observed in the studies $^{(9,18,21,24,31)}$. Another possibility is that the natural defenses antioxidant like enzyme GPx, mature along the gestation. So, in premature animal, the GPx probably are poorly developed ${ }^{(32)}$.

According to Daniels, Gibson and Simmer ${ }^{(18)}$ and Mentro, Smith and Moyer-Mileur ${ }^{(9)}$, GPx concentrations might be 
confounded by supplemental oxygen and steroids which are common practice for preterm infants. Thus according to authors, GPx activity may be a poor functional indicator of selenium status in infants ${ }^{(10,31-33)}$, especially in preterm infants ${ }^{(8,9,24,32)}$. But GPx, seems to be a good marker for adults ${ }^{(8,18,32)}$.

Prematurity also affects birth weight ${ }^{(34)}$. Birth weight is the anthropometric indicator that has the greatest influence on health and newborn survival ${ }^{(33,35-37)}$. Makhoul $e t a l^{(8)}$ and Lockitch $e a l^{(21)}$ observed that the lower the weight, the lower the concentration of selenium in newborns. Bogye, Alfthan and Machay ${ }^{(38)}$ stated that very low birth weight premature infants are obviously susceptible to selenium deficiency.

Selenium deficiency has also been associated with a greater number of diseases and clinical complications. Klinger et $a l^{(39)}$ found selenium deficiency in most premature infants however, there was not a significant correlation between selenium levels and thyroid hormones.
Merz et al ${ }^{(40)}$ found no relationship between the incidence of bronchopulmonary dysplasia and selenium status. Darlow et $a^{(24)}$ suggested that low Se concentrations may be associated an increase in risk to lung injury.

Darlow $e a l^{(32)}$ were the first to demonstrate in humans an association between low plasma selenium levels and a greater risk of lung disease, evidenced by oxygen requirement and dependency in the 28th day of life of the affected patients. Mentro, Smith and Moyer-Mileur ${ }^{(9)}$ showed that, despite a reduction in selenium plasma levels, increased selenium ingestion was associated with a reduction in oxygen dependency. In fact, selenium supplementation would act against oxidative stress caused by early exposure to an oxygen-rich environment, in addition to supplemental oxygen provided in some cases.

Daniels, Gibson and Simmerb ${ }^{(18)}$ found no significant difference in the incidence of retinopathy of prematurity

Table 3 - Main results found in publications about alterations in selenium concentration and clinical status

\begin{tabular}{|c|c|}
\hline Author/year & Results \\
\hline Darlow et al, 1995(32) & $\begin{array}{l}\text { Between } 48 \mathrm{~h} \text { and } 28 \text { days of life, it was observed that each } 0.1 \mu \mathrm{mol} / \mathrm{L} \text { decrease in } \\
\text { plasma Se was associated with a } 28 \% \text { increase in the number of days the infants } \\
\text { received } \mathrm{O}_{2}(95 \% \mathrm{Cl}-0.5-64 ; p=0.06) \text {. In the } 28 \text { th day, plasma Se was significantly } \\
\text { lower in preterm newborns with } \mathrm{CLD}(p<0.001) \text {. Mean plasma Se was lower in preterm } \\
\text { newborns with BPD. And each } 0.1 \mu \mathrm{mol} / \mathrm{L} \text { decrease in plasma Se was associated with a } \\
58 \% \text { increase in days of } \mathrm{O}_{2} \text { dependency. }\end{array}$ \\
\hline Daniels et al, 1996 (18) & $\begin{array}{l}\text { When boys were analyzed separately, it was noticed that the incidence of CLD is } \\
\text { similar between groups ( } 60 \% \text { in BW without supplementation and } 63 \% \text { in BW with } \\
\text { supplementation). }\end{array}$ \\
\hline Merz et al, $1998^{(40)}$ & Se values were not significantly different among the preterm infants with and without BPD. \\
\hline Klinger et al, 1999(39) & $\begin{array}{l}26 \text { infants was diagnosed with Se deficiency (serum levels were }<0.72 \mu \mathrm{M}) \text {. Low values } \\
\text { of T4 were found in } 10 \text { of the } 26 \text { children who also had low levels of Se, but it was not } \\
\text { observed low levels of TSH. No correlation was observed between the plasma Se and } \\
\text { T4 }(r=0.36 ; p=0.06) \text { or TSH }(r=0.06 ; p=0.76) \text {. }\end{array}$ \\
\hline
\end{tabular}

Darlow et al, 2000(24) Before randomization the mean plasma Se was $0.33 \mu \mathrm{mol} / \mathrm{l}$ in both groups. In 28 days it had increased to $0.56 \mu \mathrm{mol} / \mathrm{L}$ in the supplemented infants, but had dropped to $0.29 \mu \mathrm{mol} / \mathrm{L}$ in the infants without Se $(p<0.0001)$. The lower plasma Se found before randomization was associated with increased respiratory morbidity. After the first week, the infants with lower supplementation had an episode of sepsis $(p<0.038)$.

Winterbourn et al, 2000 (48) There was a weak negative correlation with GPx in the $36^{\text {th }}$ week (correlation coefficient, $-0.23, p=0.01$ ). Regarding MDA, there was no correlation with plasma Se and GPx at any given moment. Therefore, Se supplementation did not influence the levels of these markers.

Mentro et al, 2004(9) Se ingestion in the $1^{\text {st }}$ week was associated with a reduction in $\mathrm{O}_{2}$ dependency in the $28^{\text {th }}$ day.

BPD: bronchopulmonary dysplasia; CLD: chronic lung disease; GPx: glutathione peroxidase; GA: gestational age; LBW: low birth weight; MDA: malone dialdehyde; $\mathrm{O}_{2}$ : oxygen; $\mathrm{PN}$ : parenteral nutrition; Se: selenium. 
and intraventricular hemorrhage, but observed a higher incidence of sepsis among premature infants without selenium supplementation.

Thus, feeding newborns with an adequate amount of selenium is important to restore and to maintain selenium liver stores $^{(9)}$, preventing a number of disorders and complications, as well as to support the appropriate growth and development of newborn infants.

Daniels et $a l^{(31)}$ suggest that supplementation should be at least equivalent to the amount of selenium in breast milk of women from the same geographical region; after all, there are some regions where soils are low in selenium,

Table 4 - Main results found in publications about alterations in selenium concentrations and feeding provided

\begin{tabular}{|c|c|}
\hline Author/year & Results \\
\hline Amin et al, 1980(28) & $\begin{array}{l}\text { Premature infants without Se supplemented had low Se levels the } 2^{\text {nd }} \text { week }(0.063 \mu \mathrm{g} / \mathrm{mL}) \text {. } \\
\text { But when the preterm infants were fed with formula (with Se), the concentrations increased } \\
\text { to } 0.079 \mu \mathrm{g} / \mathrm{mL} \text { the } 4^{\text {th }}-6^{\text {th }} \text { week of age. }\end{array}$ \\
\hline Huston et al, 1991(47) & $\begin{array}{l}\text { Se concentrations dropped in infants with and without added Se when PN was } \\
\text { discontinued, but were significantly higher in the preterm infants supplemented with EN. } \\
\text { GPx demonstrated a significant increase in supplemented group with EN and then tended } \\
\text { to fall. In preterm without Se, GPx tended to increase; then dropped significantly when PN } \\
\text { was discontinued. }\end{array}$ \\
\hline Smith et al, $1991^{(29)}$ & $\begin{array}{l}\text { At the } 3^{\text {rd }} \text { week, the plasma Se was greater in preterm infants BF than the preterm infants } \\
\text { fed with } \mathrm{F}(p<0.05) \text {. There were no differences between groups for GPx concentrations. }\end{array}$ \\
\hline Darlow et al, 1995(32) & A reduction in plasma Se concentration was not significantly correlated with the $28^{\text {th }}$ day of PN. \\
\hline \multirow[t]{2}{*}{ Daniels et al, 1996(18) } & 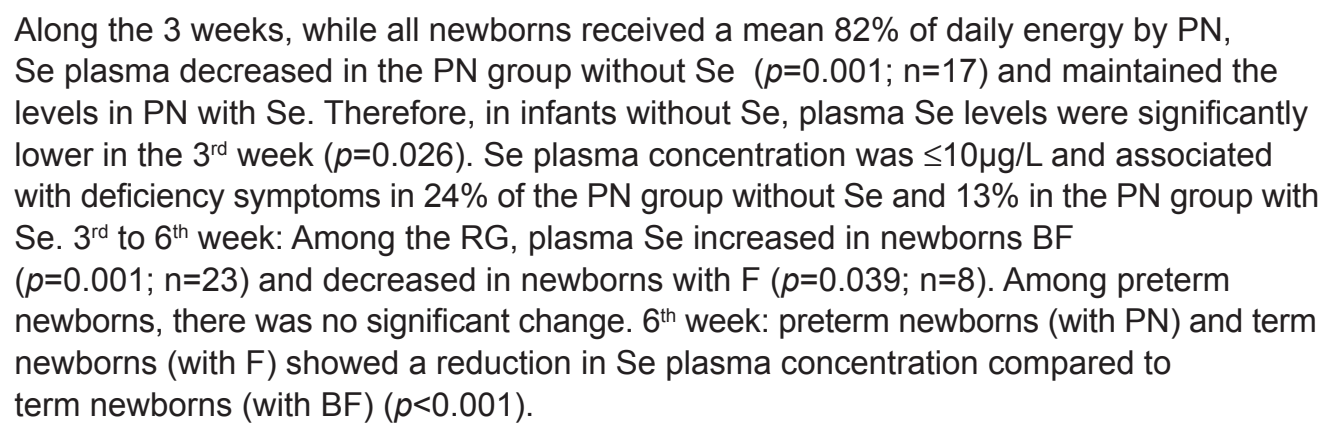 \\
\hline & $\begin{array}{l}\text { The GPx activity increased in supplemented infants }(p=0.042) \text { and there was no change } \\
\text { in unsupplemented infants }(p=0.264) \text {. There was no difference in GPx among the groups } \\
\text { at week } 3 \text { and } 6 .\end{array}$ \\
\hline Bogye et al, 1998(51) & $\begin{array}{l}\text { In the EN group without supplementation, mean serum Se concentration decreased } \\
\text { significantly in } 2 \text { weeks from } 34.4 \pm 20.4 \mu \mathrm{g} / \mathrm{L} \text { to } 26.1 \pm 16.6 \mu \mathrm{g} / \mathrm{L}(p<0.005) \text {. In the } \\
\text { supplemented group, it increased from } 36.1 \pm 12.8 \mu \mathrm{g} / \mathrm{L} \text { to } 43.5 \pm 7.9 \mu \mathrm{g} / \mathrm{L}(p<0.01) \text {. }\end{array}$ \\
\hline Bogye et al, 1998(38) & $\begin{array}{l}\text { In the EN group without supplementation, the mean serum Se concentration decreased } \\
\text { significantly in } 2 \text { weeks from } 25.9 \pm 6.8 \text { to } 18.2 \pm 6.4 \mu \mathrm{g} / \mathrm{L}(p<0.004) \text {. In the supplemented group, it } \\
\text { increased significantly from } 32.1 \pm 8.5 \text { to } 41.5 \pm 6.5 \mu \mathrm{g} / \mathrm{L}(p<0.004) \text {. }\end{array}$ \\
\hline \multirow[t]{2}{*}{ Winterbourn et al, 2000(48) } & $\begin{array}{l}\text { Supplementation resulted in a significant increase in plasma Se, virtually doubling } \\
\text { the value compared to values observed before supplementation, with the major part } \\
\text { increasing in the first week. Supplementation also prevented a decrease in GPx, already } \\
\text { showing a statistically significant difference in the } 1^{\text {st }} \text { week between groups. }\end{array}$ \\
\hline & $\begin{array}{l}\text { There was no significant difference in carbonyl protein concentrations and MDA between } \\
\text { the supplemented group and the non-supplemented group. }\end{array}$ \\
\hline
\end{tabular}

BF: breastfed; EN: enteral nutrition; F: oral infant formula; GPx: glutathione peroxidase; MDA: malone dialdehyde; PN: parenteral nutrition; RG: reference group; Se: selenium. 
as in New Zealand ${ }^{(32)}$, Switzerland ${ }^{(41)}$, China ${ }^{(42)}$ and some states of $\mathrm{Brazil}^{(43)}$.

Makhoul et $a l^{(8)}$ stated that infants fed with maternal milk, regardless of being premature or not, do not require selenium supplementation. However, when feeding of these infants is based on infant formula, enteral or parenteral nutrition, supplementation is necessary even in term newborn infants.

Most publications studied in this review showed an association between feeding provided to infants — infant formulas administered by oral, enteral or parenteral route containing little or no addition of selenium - and low selenium concentrations ${ }^{(9,18,23,28,31,32,44)}$.

The current recommendations for selenium supplements are based on the ingestion of selenium by infants fed with maternal milk, since it appears to meet newborn requirements $^{(15,31,33)}$.

Currently, ASPEN (2012) ${ }^{(13)}$ recommends $2 \mu \mathrm{g} / \mathrm{kg} /$ day selenium in parenteral nutrition for the pediatric population. There is no differentiation between preterm and term neonates, healthy and sick neonates, and between neonates with appropriate or low birth weight for gestational age.

Surveys claim that selenium concentrations are lower in preterm infants, especially in those with low birth weight $(<1,500 \mathrm{~g})$ and very low birth weight $(<1,000 \mathrm{~g})$, when compared with term infants $s^{(22,37,38,45,46)}$.

Daniels, Gibson and Simmer ${ }^{(18)}$, studying preterm infants receiving parenteral nutrition, found selenium levels similar to those observed in children with Keshan disease. Huston, Jelen and Vidgoff ${ }^{(47)}$ concluded that adding $1.34 \mu \mathrm{g} / \mathrm{kg} /$ day of selenium in PN is not adequate for LBW. Those authors additionally suggested that supplementation with $3 \mu \mathrm{g} / \mathrm{kg} / \mathrm{day}$ of selenious acid was incapable of preventing significant decreases in plasma selenium concentration when compared with term newborn infants fed breast milk ${ }^{(18)}$. This fact is concerning, since, according to the literature, supplementation may revert several clinical complications, although it is not efficient for reverting Keshan disease.

Klinger et $a^{(39)}$ reported that supplementation of $2 \mu \mathrm{g} / \mathrm{kg} /$ day of selenium has not been able to prevent or reverse selenium deficiency. Thus, the authors support the recommendation to review premature infants guidelines. Makhoul et al ${ }^{(8)}$ suggested that measurement of selenium levels recommended in parenteral nutrition should increase twofold (up to $7 \mu \mathrm{g} / \mathrm{kg} /$ day).

In a research conducted by Darlow ${ }^{(24)}$, supplementation prevented the fall and achieved levels similar to those reported in term infants fed human milk. So, the authors suggest that VLBW infants should receive sufficient supplementation to achieve levels observed in term infants fed human milk, despite the minimal benefits in the clinical picture found in research.

In a study by Winterbourn et al ${ }^{(48)}$, supplementation $(7 \mu \mathrm{g} / \mathrm{kg} /$ day and $5 \mu \mathrm{g} / \mathrm{kg} /$ day of sodium selenite in parenteral and oral nutrition, respectively) did not have an effect on oxidative stress, although selenium levels almost doubled and GPx showed a significant difference between groups with and without supplementation. This fact may be explained by the inadequate dose of selenium, the late supplementation, and also due to the scant evidence of oxidative stress among premature infants.

Despite the discussion about the optimal dose and length of selenium supplementation, several studies have shown that the addition of selenium may prevent diseases and their complications $^{(6,17,49,51)}$, including a shortened hospital stay and, consequently, lower financial costs.

\section{Conclusion}

Nutritional assessment of selenium status in the body to analyze biochemical indicators and clinical manifestations should be performed, especially in premature newborns who were not breastfed. Blood selenium concentrations are reduced in neonates, especially in those with lower gestational age and birth weight. Furthermore, newborn infants who are not breastfed and supplemented show the lowest selenium levels, including newborns, without any underlying disease. Therefore, supplementation is important in preterm infants who were not breastfed in order to minimize the risks of diseases and complications associated with selenium deficiency, contributing to a healthy growth and development of the child.

The optimal dose and length of selenium supplementation have still not been well-established, since they are based only on age group and selenium ingestion in breastfed children. Furthermore, the clinical status of the infants affected by conditions that may increase oxidative stress and, consequently, increase selenium requirements, was not taken into account.

Thus, studies into this subject area are strictly necessary to encourage selenium supplementation in all countries and healthcare services, for the prevention or reversal of selenium deficiency and the resultant complications in humans, especially among newborn infants. 


\section{References}

1. Porras IC, Muriel AC, Morales BO, Pozo JF, Aranda JG, Pérez L. Evaluación de nutrición parenteral estandarizada en niños. Nutr Hosp 2010;25:449-55.

2. Uslu N, Saltik-Temizel IN, Demir H, Gürakan F, Özen H, Yüce A. Serum selenium concentrations in cirrhotic children. Turk J Gastroenterol 2010;21:153-5

3. Cominetti C, de Bortoli MC, Purgatto E, Ong TP, Moreno FS, Garrido Jr AB et al. Associations between glutathione peroxidase-1 Pro198Leu polymorphism, selenium status, and DNA damage levels in obese women after consumption of Brazil nuts. Nutrition 2011;27:891-6.

4. Ashton K, Hooper L, Harvey LJ, Hurst R, Casgrain A, Fairweather-Tait SJ. Methods of assessment of selenium status in humans: a systematic review. Am J Clin Nutr 2009;89:2025S-39S.

5. Harrison I, Littlejohn D, Fell GS. Distribution of selenium in human blood plasma and serum. Analyst 1996;121:189-94.

6. Nogueira RJ, Lima AE, Prado CC, Ribeiro AF. Nutrição em pediatria oral, enteral e parenteral. São Paulo: Sarvier; 2011.

7. Keshan Disease Research Group. Observations on effect of sodium selenite in prevention of Keshan disease. Chin Med J (Engl) 1979;92:471-6.

8. Makhoul IR, Sammour RN, Diamond E, Shohat I, Tamir A, Shamir R. Selenium concentrations in maternal and umbilical cord blood at 24-42 weeks of gestation: basis for optimization of selenium supplementation to premature infants. Clin Nutr 2004;23:373-81.

9. Mentro AM, Smith AM, Moyer-Mileur L. Plasma and erythrocyte selenium and glutathione peroxidase activity in preterm infants at risk for bronchopulmonary dysplasia. Biol Trace Elem Res 2005;106:97-106.

10. Nassi N, Ponziani V, Becatti M, Galvan P, Donzelli G. Anti-oxidant enzymes and related elements in term and preterm newborns. Pediatr Int 2009;51:183-7.

11. National Health and Medical Research Council. Nutrient Reference Values for Australia and New Zealand. Canberra: Commonwealth of Australia; 2006.

12. Koletzko B, Goulet O, Hunt J, Krohn K, Shamir R. Guidelines on Paediatric Parenteral Nutrition of the European Society of Paediatric Gastroenterology, Hepatology and Nutrition (ESPGHAN) and the European Society for Clinical Nutrition and Metabolism (ESPEN), Supported by the European Society of Paediatric Research (ESPR). J Pediatr Gastroenterol Nutr 2005;41 (Suppl 2):S1-87.

13. Vanek VW, Borum P, Buchman A, Fessler TA, Howard L, Jeejeebhoy K et al. A.S.P.E.N. position paper: recommendations for changes in commercially available parenteral multivitamin and multi-trace element products. Nutr Clin Pract 2012;27:440-91.

14. Canada T, Crill C, Guenter P. A.S.P.E.N. Parenteral nutrition handbook. Silver Spring: American Society Parenteral for Parenteral and Enteral Nutrition; 2009.

15. Forchielli ML. Pediatric nutrition in your pocket. Silver Spring: American Society for Parenteral and Enteral Nutrition; 2002.

16. Rayman JM. The importance of selenium to human health. Lancet 2000;356:233-41.

17. Dylewski ML, Bender JC, Smith AM, Prelack K, Lydon M, Weber J et al. The selenium status of pediatric patients with burn injuries. J Trauma 2010;69:584-88.

18. Daniels L, Gibson R, Simmer K. Randomised clinical trial of parenteral selenium supplementation in preterm infants. Arch Dis Child Fetal Neonatal Ed 1996;74:F158-64.

19. Kien CL, Ganther HE. Manifestations of chronic selenium deficiency in a child receiving total parenteral nutrition. Am J Clin Nutr 1983;37:319-28.

20. Associação Médica Brasileira, Conselho Federal de Medicina [homepage on the Internet]. Projeto Diretrizes - Associação Médica Brasileira e Conselho Federal de Medicina [cited 2013 Jul 10]. Available from: http:// www.portalmedico.org.br/diretrizes/100_diretrizes/Texto_Introdutorio.pdf

21. Lockitch G, Jacobson B, Quigley G, Dison P, Pendray M. Selenium deficiency in low birth weight neonates: an unrecognized problem. J Pediatr 1989;114:865-70.
22. Trindade CE. Importância dos minerais na alimentação do pré-termo extremo. J Pediatr (Rio J) 2005;81 (Suppl 1):s43-51.

23. Muntau AC, Streiter M, Kappler M, Röschinger W, Schmid I, Rehnert A et al Age-related reference values for serum selenium concentrations in infants and children. Clin Chem 2002;48:555-60.

24. Darlow BA, Winterbourn CC, Inder TE, Graham PJ, Harding JE, Weston PJ et al. The effect of selenium supplementation on outcome in very low birth weight infants: a randomized controlled trial. J Pediatr 2000;136:473-80.

25. Friel JK, Andrews WL, Long DR, L'Abbe MR. Selenium status of very low birth weight infants. Pediatr Res 1993;34:293-6.

26. Hambidge KM. Trace element requirements in the premature infants. In: Lebenthal E, editor. Textbook of gastroenterology and nutrition in infancy. $2^{\text {nd }}$ ed. New York: Raven Press; 1992. p. 393-401.

27. Mask GR, Lane HW. Selected measures of selenium status in full-term and preterm neonates, their mothers and nonpregnant women. Nutr Res 1993;13:901-11.

28. Amin S, Chen SY, Collipp PJ, Castro-Magana M, Maddaiah VT, Klein SW Selenium in premature infants. Nutr Metab 1980;24:331-40.

29. Smith AM, Chan GM, Moyer-Mileur LJ, Johnson CE, Gardner BR. Selenium status of preterm infants fed human milk, preterm formula, or seleniumsupplemented preterm formula. J Pediatr 1991;119:429-33.

30. Galinier A, Périquet B, Lambert W, Garcia J, Assouline C, Rolland M et al Reference range for micronutrients and nutritional marker proteins in cord blood of neonates appropriated for gestational ages. Early Hum Dev 2005;81:583-93.

31. Daniels L, Gibson RA, Simmer K, Van Dael P, Makrides M. Selenium status of term infants fed selenium-supplemented formula in a randomized doseresponse trial. Am J Clin Nutr 2008;88:70-6.

32. Darlow BA, Inder TE, Graham PJ, Sluis KB, Malpas TJ, Taylor BJ et al. The relationship of selenium status to respiratory outcome in the very low birth weight infant. Pediatrics 1995;96:314-9.

33. Food and Nutrition Board, Institute of Medicine. Dietary reference intakes for vitamin C, vitamin E, selenium and carotenoids. Washington, DC: National Academy Press; 2002.

34. Monteiro CA, Benicio MH, Ortiz LP. Tendência secular do peso ao nascer na cidade de São Paulo (1984-1996). Rev Saude Publica 2000;34 (Suppl 6):26-40.

35. Kilsztajn S, Rossbach A, Nunes do Carmo MS, Sugahara GT. Assistência pré-natal, baixo peso e prematuridade no Estado de São Paulo, 2000. Rev Saude Publica 2003;37:303-10.

36. Nascimento LF, Gotlieb SL. Fatores de risco para o baixo peso ao nascer com base em informações da declaração de nascido vivo em Guaratinguetá, SP, 1998. Inf Epidemiol SUS 2001;10:113-20.

37. Cormick MC. The contribution of low birth weight to infant mortality and childhood morbidity. N Engl J Med 1985;312:82-90.

38. Bogye G, Alfthan G, Machay T. Randomized clinical trial of enteral yeastselenium supplementation in preterm infants. Biofactors 1998;8:139-42.

39. Klinger G, Shamir R, Singer P, Diamond EM, Josefsberg Z, Sirota L. Parenteral selenium supplementation in extremely low birth weight infants: inadequate dosage but no correlation with hypothyroidism. J Perinatol 1999;19:568-72.

40. Merz U, Peschgens $T$, Dott $W$, Hörnchen $H$. Selenium status and bronchopulmonary dysplasia in premature infants $<1,500 \mathrm{~g}$. Z Geburtshilfe Neonatol 1998;202:203-6

41. Eichholzer M. Micronutrient deficiencies in Switzerland: causes and consequences. J Food Eng 2003;56:171-9.

42. Xia Y, Hill KE, Burk RF. Biochemical studies of a selenium-deficient population in China: measurement of selenium, glutathione peroxidase and other oxidant defense indices in blood. J Nutr 1989;119:1318-26.

43. Moraes MF, Welch RM, Nutti MR, Carvalho JL, Watanabe E. Evidences of selenium deficiency in Brazil: from soil to human nutrition. Proceedings of the First International Conference on Selenium in the Environment and Human Health; 2009; Suzhou, China. p. 73-4. 
44. Andrews PJ, Avenell A, Noble DW, Campbell MK, Battison CG, Croal BL et al. Randomised trial of glutamine and selenium supplemented parenteral nutrition for critically ill patients. Protocol Version 9, 19 February 2007 known as SIGNET (Scottish Intensive care Glutamine or seleNium Evaluation Trial). Trials 2007;8:25.

45. Sievers E, Arpe T, Schleyerbach U, Garbe-Schönberg D, Schaub J. Plasma selenium in preterm and term infants during the first 12 months of life. $J$ Trace Elements Med Biol 2001;14:218-22.

46. Klein CJ. Nutrient requirements for preterm infant formulas. Minerals: calcium and phosphorus. J Nutr 2002;132:1395S-577S.

47. Huston RK, Jelen BJ, Vidgoff J. Selenium supplementation in low-birthweight premature infants: relationship to trace metals and antioxidant enzymes. JPEN J Parenter Enteral Nutr 1991;15:556-9.
48. Winterbourn CC, Chan T, Buss IH, Inder TE, Mogridge N, Darlow BA. Protein carbonyls and lipid peroxidation products as oxidation markers in preterm infant plasma: associations with chronic lung disease and retinopathy and effects of selenium supplementation. Pediatr Res 2000;48:84-90.

49. Forceville LX. Selenium and the "free" electron. Selenium - a trace to be followed in septic or inflammatory ICU patients? Intensive Care Med 2001;27:16-8.

50. Heyland DK, Dhaliwal R, Suchner U, Berger MM. Antioxidant nutrients: a systematic review of trace elements and vitamins in the critically ill patient. Intensive Care Med 2005;31:327-37.

51. Bogye G, Alfthan G, Machay T, Zubovics L. Enteral yeast-selenium supplementation in preterm infants. Arch Dis Child Fetal Neonatal Ed 1998;78:F225-6. 